Kalpa Publications in Engineering
Volume 1, 2017, Pages 537-547
ICRISET2017. International Conference on Re-
search and Innovations in Science, Engineering
\&Technology. Selected Papers in Engineering

\title{
Experimenting and Predicting Flatness and Surface Roughness during Face Milling Operation of CF8M Grade A-351
}

\author{
Purvi Chauhan ${ }^{1}$,Sagar Patel ${ }^{2}$, Karan Patel ${ }^{3}$ \\ ${ }^{1}$ Assistant Professor, \\ Production Engineering Department \\ BVM Engineering College \\ V.V.Nagar,Anand. \\ ${ }^{2,3}$ B.E.Student, Production Engineering Department \\ BVM Engineering College \\ V.V.Nagar,Anand.
}

\begin{abstract}
Surface flatness and roughness has a pivotal role in the functioning of any kind of check valve. These two parameters are mainly obtained by face milling[16] during the manufacturing process of valves. The values of these affect during leakage rejection and redesign of check valves. To achieve the desired values of surface flatness and roughness here analysis is carried out. A regression model is generated to predict the values of surface roughness and flatness. ANOVA is also developed to see the effect of machining process parameters on the surface roughness and flatness.
\end{abstract}

Keywords- Face milling, Surface roughness, Flatness, CF8M material, Dual plate check valve, Coordinate Measuring Machine. 


\section{Introduction}

There are various materials used for manufacturing of valves but one of worldwide used material is CF8M. During making of any check valves material plays crucial role and depending upon it further factors are decided. CF8M material mainly possesses high resistance towards corrosion so it has been preferred for making valves. The flatness on the milling components is of prime importance as in case of dual plate check valve, so that the components (body and door) assemble together properly and create metal to metal seal without significant rocking. So, the investigation of flatness and surface roughness of CF8M material creates new scientific domain in the machining. The selection of proper cutting parameters for milling process becomes a vital requirement for reduction of rework and to increase the productivity. Few main parameters like Spindle speed, Feed rate and Depth of Cut are considered for the present investigation. Their right selection may optimize the surface flatness and roughness error during machining.

\subsection{Valve Manufacturing Process}

Step -1 Designing of the valve as per customer requirements, Step- 2 Selection of material to be used in manufacturing of the valve, Step- 3 Valves made by casting, forging etc., Step- 4 Machining of valves using HMC, VMC and CNC machines, Step- 5 Grinding and finishing of the valve, Step- 6 Inspection and leakage testing of the valve, Step- 7 Color coating, coding and final dispatch of the valve.

\subsection{Literature review}

Milon et al found the use of Taguchi technique and Geneticic Algorithm (GA) for minimizing the surface roughness by machining mild steel with three zinc coated carbide tools inserted into a face miller of $25 \mathrm{~mm}$ diameter.[4]. The face milling operation is to be performed on the hard

faced surfaces, which is obtained through MIG welding [1,2] Flatness and surface roughness play a vital role in achieving the metal to metal seal. Now the value of flatness as geometric tolerance is highly process dependent. The Flatness values may be measured using dial indicator, CMM or by other indirect methods [3]. Sheth et al. investigate the effect of cutting parameters on flatness and surface roughness for dual plate check valve for WCB material for face milling operation[5,6].Patel et al. investigate the effect of various parameters on Material removal rate and spread in flashing operation of precision steel ball manufacturing process[6,8,9]. Sheth et al. investigate the effect of cutting parameters during drilling of WCB material using grey relational analysis [12]. Surasit Rawangwong, Jaknarin Chatthong, Romadorn Burapa, and Worapong Boonchouytan et al. investigate the main factors on the surface roughness in semi-solid AA 7075 face milling.[15]

\section{Experimental Design Setup}

2.1 Workpiece Material

The test work piece material is CF8M with grade A -351 with $50 \times 40 \times 40$ size. Its chemical composition is given below. It is widely used material in manufacturing of valves due to its less cost as compared to other materials. Chemical composition and mechanical properties of CF8M material: - 
TABLE-1: Chemical composition of CF8M material

\begin{tabular}{|c|c|}
\hline Steel type & Stainless steel \\
\hline $\begin{array}{c}\text { Metal code, } \\
\text { Standard }\end{array}$ & CF8M, ASTM A316 \\
\hline $\mathrm{C}$ & $0.30 \%$ \\
\hline $\mathrm{Si}$ & $1.50 \%$ \\
\hline $\mathrm{Mn}$ & $1.50 \%$ \\
\hline $\mathrm{P}$ & $0.040 \%$ \\
\hline $\mathrm{S}$ & $0.040 \%$ \\
\hline $\mathrm{Cr}$ & $21.00 \%$ \\
\hline $\mathrm{Ni}$ & $18.00 \%$ \\
\hline $\mathrm{M} 0$ & $0.30 \%$ \\
\hline $\mathrm{Cu}$ & $0.30 \%$ \\
\hline $\mathrm{V}$ & $0.03 \%$ \\
\hline
\end{tabular}

\subsection{Machine and cutting tool}

Face milling was performed on the 3-axis CHIRON FZ 16 L/CNC milling machine having spindle motor power of $5.8 \mathrm{kw}$ with Cubic Boron Nitride $(\mathrm{CBN})$ coated inserts where six inserts tool were used. Tool diameter is of $50 \mathrm{~mm}$.

$\mathrm{CBN}$ is the second hardest material after synthetic diamond which is synthesized from hexagonal boron nitride. It possess excellent hot hardness that can be used for machining at very high cutting speed while it also shows good toughness and high thermal shock resistance. Another physical advantage of CBN as compared to the conventional abrasive is that in addition to keep hardness at normal temperature it maintains hardness over a wide temperature range. Other advantage includes improved surface finish and the production of more favourable compressive residual surface stresses [13].

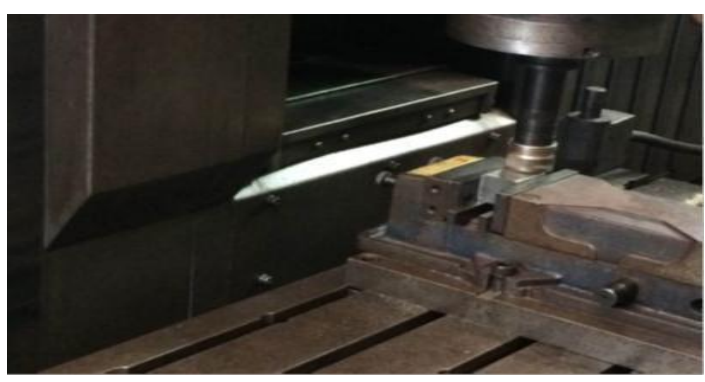

Fig-1: Face milling process on CF8M square piece 


\subsection{Experimental Procedure}

Experiments (milling operation) was carried out on four cube blocks of CF8M material having dimensions, length $=50 \mathrm{~mm}$, breadth $=40 \mathrm{~mm} \&$ height $=40 \mathrm{~mm}$. Spindle speed, feed and depth of cut were selected as input variables to perform experiments according to $2^{\wedge} 3$ full factorial experimental design [7]. The blocks were clamped with the help of hydraulic vice as shown in Figure-1. Two faces of every four blocks were initially machined and then face milling operation was carried out on the machined surfaces of the blocks. During the operation, number of passes and coolant flow rate were kept constant. The machined components are shown in Figure2-

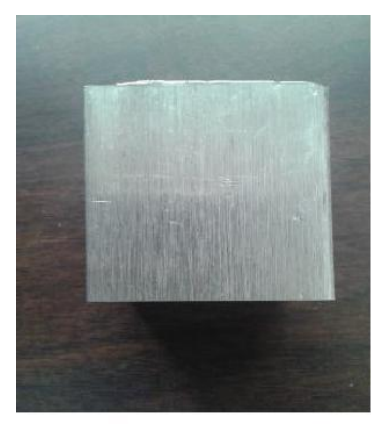

Before Machining

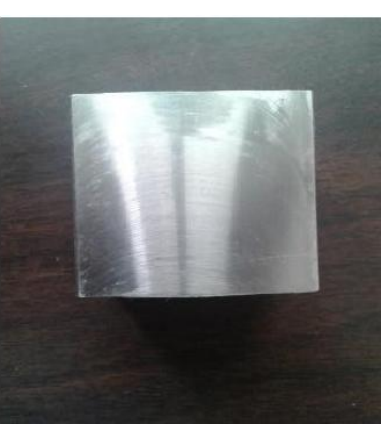

After Machining

Fig-2: Machined Blocks

\subsection{Design of Experiments}

DOE is performed onto a process to improve its capability. It is carried out by conducting a series of experiment to study the change in output variable by bringing intentional and measured changes in the input variable of process which is always desirable to a quality problem. For design of experiment three variables speed, feed and depth of cut with two levels were selected as shown in table below:

TABLE -2 Variables with maximum and minimum range

\begin{tabular}{|c|c|c|c|}
\hline $\begin{array}{l}\text { Code } \\
\text { d } \\
\text { Facto } \\
\text { r }\end{array}$ & Variables & $\begin{array}{ll} & L \\
\text { ow } & \\
\text { vel } & \\
& (-) \\
\end{array}$ & $\begin{array}{r}\mathrm{Hi} \\
\mathrm{gh} \\
\mathrm{lev} \\
\mathrm{el} \\
(+) \\
\end{array}$ \\
\hline A & Speed(rpm) & $0^{84}$ & $50^{10}$ \\
\hline B & Feed(mm/min) & $0^{15}$ & $0^{25}$ \\
\hline $\mathrm{C}$ & Depth of $\operatorname{cut}(\mathrm{mm})$ & 0.3 & 0.5 \\
\hline
\end{tabular}




\subsection{Measuring Techniques}

\subsubsection{CMM}

A Coordinate Measuring Machine is a basic device for measuring the physical geometrical characteristics of an object. Flatness measurement was carried out on manual Mitutoyo Crysta-Plus M443 [14] co-ordinate measuring machine as shown in Figure-3. For measuring flatness, 65 points were taken manually on the machined surface of the blocks and simultaneously readings were taken from the computer monitor.

2.5.2 Surface Roughness Tester

Surf Test sv-2100 column type surface roughness tester is a high precision and high performance tester with a dedicated controlled unit with user friendly display and simple operation.Surface roughness measuring was carried out on Surf test SV-2100 as shown in Figure-4. The machine gives roughness values in micro $\mathrm{mm}$ on a digital monitor display. Cut off length for measurement of surface roughness is approx $20 \mathrm{~mm}$.

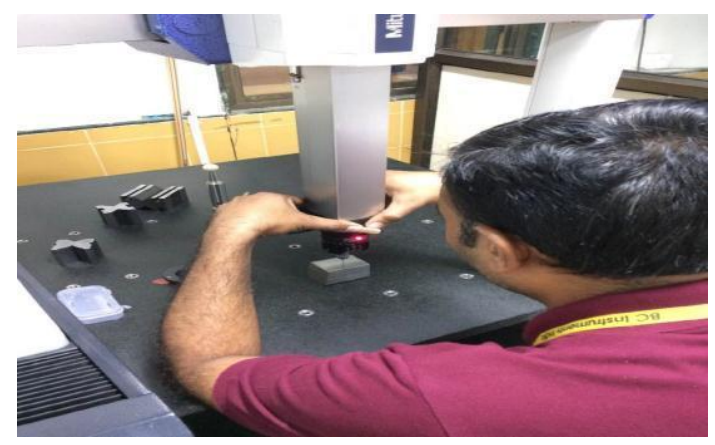

Fig-3: Measurement of flatness by CMM (Mitutoyo Crystal-Plus M443)

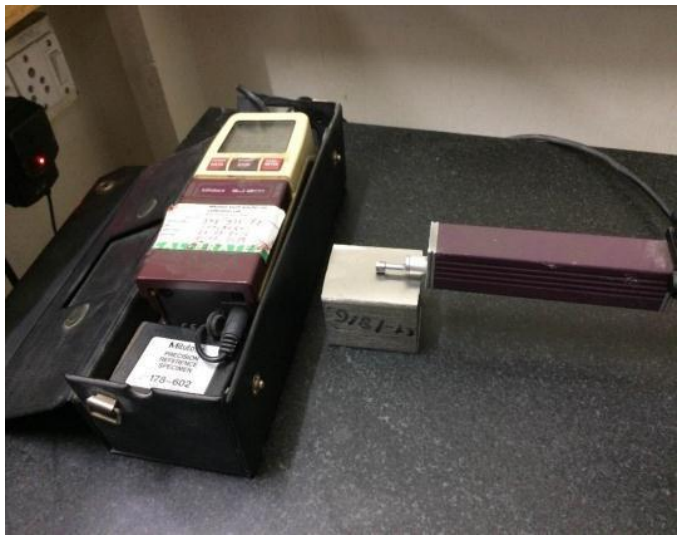

Fig-4: Measurement of roughness by surface roughness tester (surf test sv-2100) 


\section{Result and Analysis}

Following table shows design of experiment for various combinations.

TABLE-3 Experimental set up for flatness and roughness

\begin{tabular}{|c|c|c|c|c|c|}
\hline $\begin{array}{l}\text { Treat } \\
\mathrm{m} \\
\text { ent } \\
\text { combi } \\
\mathrm{n} \\
\text { ation }\end{array}$ & $\begin{array}{c}\text { Speed } \\
(\mathrm{rpm})\end{array}$ & 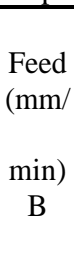 & $\begin{array}{c}\text { Dept } \\
\mathrm{h} \\
\text { of } \\
\operatorname{cut}(\mathrm{m} \\
\mathrm{m}) \\
\mathrm{C}\end{array}$ & $\begin{array}{l}\text { Flatne } \\
\text { ss } \\
(\mathrm{mm})\end{array}$ & $\begin{array}{l}\text { Roug } \\
\mathrm{h} \\
\text { ness } \\
(\mu \mathrm{m})\end{array}$ \\
\hline 1 & 840 & 150 & 0.3 & $\begin{array}{c}0.0303 \\
3\end{array}$ & 1.52 \\
\hline$a$ & 1050 & 150 & 0.3 & $\begin{array}{c}0.0165 \\
1 \\
\end{array}$ & 0.55 \\
\hline$b$ & 840 & 250 & 0.3 & $\begin{array}{c}0.0306 \\
1\end{array}$ & 0.51 \\
\hline$c$ & 840 & 150 & 0.5 & $\begin{array}{l}0.0288 \\
6 \\
\end{array}$ & 1.56 \\
\hline$a b$ & 1050 & 250 & 0.3 & $\begin{array}{l}0.0158 \\
4\end{array}$ & 0.48 \\
\hline$a c$ & 1050 & 150 & 0.5 & $\begin{array}{l}0.0151 \\
2\end{array}$ & 0.65 \\
\hline$b c$ & 840 & 250 & 0.5 & $\begin{array}{c}0.0337 \\
6\end{array}$ & 1.17 \\
\hline$a b c$ & 1050 & 250 & 0.5 & $\begin{array}{c}0.0157 \\
8\end{array}$ & 0.48 \\
\hline
\end{tabular}

Here 1, a ,b, c, ab, ac ,bc \& abc are treatment combination of high and low level of speed, feed and depth of cut for Example-[1] has a low level of all variable, the combination [a] has a high level of speed and low level of feed and depth of cut.

According to above setup, experiments were performed for different combinations of speed, feed and depth of cut after which the obtained values of surface flatness and roughness for were jotted down in following tables: 
TABLE-4 Effective estimate summary for flatness

\begin{tabular}{|l|l|l|l|}
\hline Factor & $\begin{array}{l}\text { Effect } \\
\text { Estimate }\end{array}$ & $\begin{array}{l}\text { Sum of } \\
\text { square }\end{array}$ & $\begin{array}{l}\% \\
\text { contribution }\end{array}$ \\
\hline $\mathbf{A}$ & $\mathbf{- 0 . 0 0 5 7 5}$ & $\mathbf{0 . 0 0 0 0 6 6 2 9}$ & $\mathbf{1 8 . 8 9}$ \\
\hline $\mathrm{B}$ & -0.00802 & 0.00000805 & 2.29 \\
\hline $\mathrm{C}$ & 0.00005 & 0.00000061 & 0.01 \\
\hline $\mathrm{AB}$ & -0.00134 & 0.00000363 & 1.03 \\
\hline AC & $\mathbf{0 . 0 0 8 6 2}$ & $\mathbf{0 . 0 0 0 1 4 8 8 6}$ & $\mathbf{4 2 . 4 3}$ \\
\hline BC & $\mathbf{- 0 . 0 0 7 8 3}$ & $\mathbf{0 . 0 0 0 1 2 2 6 9}$ & $\mathbf{3 4 . 9 4}$ \\
\hline $\mathrm{ABC}$ & -0.00082 & 0.00000135 & 0.38 \\
\hline
\end{tabular}

TABLE-5 Effective estimate summary for Roughness

\begin{tabular}{|l|l|l|l|}
\hline Factor & $\begin{array}{l}\text { Effect } \\
\text { Estimate }\end{array}$ & $\begin{array}{l}\text { Sum } \\
\text { of } \\
\text { square }\end{array}$ & $\begin{array}{c}\% \\
\text { contribution }\end{array}$ \\
\hline $\mathbf{A}$ & $\mathbf{- 0 . 4 0}$ & $\mathbf{0 . 3 3 2 1}$ & $\mathbf{4 4 . 5 8}$ \\
\hline $\mathrm{B}$ & -0.41 & 0.0210 & 2.82 \\
\hline $\mathbf{C}$ & $\mathbf{0 . 0 2}$ & $\mathbf{0 . 0 8 0 0}$ & $\mathbf{1 0 . 7 4}$ \\
\hline $\mathbf{A B}$ & $\mathbf{0 . 2 9}$ & $\mathbf{0 . 1 6 8 2}$ & $\mathbf{2 2 . 5 8}$ \\
\hline $\mathrm{AC}$ & -0.15 & 0.0450 & 6.04 \\
\hline $\mathrm{BC}$ & 0.13 & 0.0338 & 4.53 \\
\hline $\mathrm{ABC}$ & -0.18 & 0.0648 & 8.70 \\
\hline
\end{tabular}

In the above Tables- 4 and 5 , percent contribution column has some black colored values, which indicates that the variable and its combination has significant effect on the machining operation

\subsection{Regression model}

Regression model widely used to predict the responses is an algebraic representation of the regression line and is used to describe the relationship between the responses and predictor variables.

Response $=$ constant + coefficient $($ predictor $)+\ldots+$ Coefficient (predictor) .

According to upper estimate effect the regression analysis will give two equations for Surface Roughness and Flatness given below:

$$
\begin{aligned}
& \mathrm{Y}=\beta 0+\beta 1 \times 1+\beta_{2} \times 2+\beta 12 \times 1 \times 2 \ldots \ldots .+\beta_{\mathrm{jkxj} x \mathrm{xk}}
\end{aligned}
$$

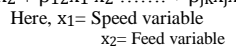

$$
\begin{aligned}
& \mathrm{x} 3=\text { Depth of cut variable }
\end{aligned}
$$


So, for Flatness:

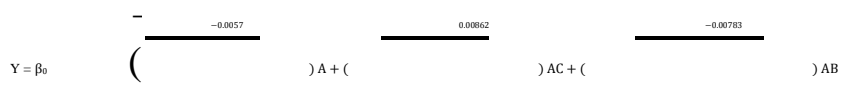

And Similarly For Roughness:

So, for Roughness:

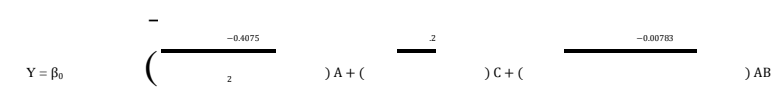

\section{ANOVA (Analysis of Variance)}

Table-5: ANOVA for Flatness:-

\begin{tabular}{|c|c|c|c|c|c|c|c|}
\hline Sou & $\begin{array}{c}\text { D.O } \\
\text {.F. }\end{array}$ & $\begin{array}{c}\text { Sum } \\
\text { of } \\
\text { squar } \\
\mathrm{e}\end{array}$ & $\begin{array}{l}\text { Adj. } \\
\text { Sum } \\
\text { of } \\
\text { squar } \\
\text { e }\end{array}$ & $\begin{array}{l}\text { Adj. } \\
\text { mean } \\
\text { squar } \\
\text { e }\end{array}$ & $\begin{array}{l}\text { P- } \\
\text { valu } \\
\mathrm{e}\end{array}$ & $\begin{array}{c}\text { F- } \\
\text { valu } \\
\text { e }\end{array}$ & $\begin{array}{l}\% \\
\text { cont } \\
\text { ribu } \\
\text { tion }\end{array}$ \\
\hline$\overline{\mathrm{A}}$ & 1 & $\begin{array}{c}0.000 \\
06629\end{array}$ & $\begin{array}{c}0.000 \\
06629\end{array}$ & $\begin{array}{c}0.000 \\
03145\end{array}$ & $\begin{array}{c}0.000 \\
142\end{array}$ & $\begin{array}{c}4.60 \\
011\end{array}$ & $\begin{array}{c}18.8 \\
9\end{array}$ \\
\hline $\bar{B}$ & 1 & $\begin{array}{c}0.000 \\
00805\end{array}$ & $\begin{array}{c}0.000 \\
00805\end{array}$ & $\begin{array}{r}0.000 \\
00402\end{array}$ & $\begin{array}{c}0.000 \\
142\end{array}$ & $\begin{array}{c}4.60 \\
011\end{array}$ & 2.29 \\
\hline $\bar{C}$ & 1 & $\begin{array}{r}0.000 \\
00061\end{array}$ & $\begin{array}{c}0.000 \\
00061\end{array}$ & $\begin{array}{c}0.000 \\
00030 \\
5\end{array}$ & $\begin{array}{c}0.000 \\
142\end{array}$ & $\begin{array}{c}4.60 \\
011\end{array}$ & 0.01 \\
\hline$\overline{\mathrm{AB}}$ & 1 & $\begin{array}{c}0.000 \\
00363\end{array}$ & $\begin{array}{c}0.000 \\
00363\end{array}$ & $\begin{array}{c}0.000 \\
00181 \\
5\end{array}$ & $\begin{array}{c}0.000 \\
142\end{array}$ & $\begin{array}{c}4.60 \\
011\end{array}$ & 1.03 \\
\hline$\overline{\mathrm{BC}}$ & 1 & $\begin{array}{c}0.000 \\
14886\end{array}$ & $\begin{array}{c}0.000 \\
14886\end{array}$ & $\begin{array}{r}0.000 \\
07443\end{array}$ & $\begin{array}{c}0.000 \\
142\end{array}$ & $\begin{array}{c}4.60 \\
011\end{array}$ & $\begin{array}{c}42.4 \\
3\end{array}$ \\
\hline$\overline{\mathrm{AC}}$ & 1 & $\begin{array}{c}0.000 \\
12269\end{array}$ & $\begin{array}{c}0.000 \\
12269\end{array}$ & $\begin{array}{c}0.000 \\
06134 \\
5\end{array}$ & $\begin{array}{c}0.000 \\
142\end{array}$ & $\begin{array}{c}4.60 \\
011\end{array}$ & $\begin{array}{c}34.9 \\
4\end{array}$ \\
\hline $\begin{array}{c}\mathrm{AB} \\
\mathrm{C}\end{array}$ & 2 & $\begin{array}{c}0.000 \\
00135\end{array}$ & $\begin{array}{r}0.000 \\
00135\end{array}$ & $\begin{array}{c}0.000 \\
00067 \\
5\end{array}$ & $\begin{array}{c}0.000 \\
142\end{array}$ & $\begin{array}{c}4.60 \\
011\end{array}$ & 0.38 \\
\hline $\begin{array}{c}\text { Tota } \\
1\end{array}$ & 15 & $\begin{array}{c}0.000 \\
35204\end{array}$ & & & & & \\
\hline
\end{tabular}


Table-6: ANOVA for Roughness:-

\begin{tabular}{|c|c|c|c|c|c|c|c|}
\hline $\begin{array}{l}\text { Sou } \\
\mathrm{r} \\
\mathrm{ce}\end{array}$ & $\begin{array}{c}\text { D. } \\
\text { O. } \\
\text { F. }\end{array}$ & $\begin{array}{l}\text { Sum } \\
\text { of } \\
\text { squa } \\
\text { re }\end{array}$ & $\begin{array}{c}\text { Adj.Su } \\
\text { m of } \\
\text { square }\end{array}$ & $\begin{array}{c}\text { Adj. } \\
\text { mea } \\
\text { n } \\
\text { squ }\end{array}$ & $\begin{array}{c}\text { P- } \\
\text { value }\end{array}$ & $\begin{array}{c}\text { F- } \\
\text { value }\end{array}$ & $\begin{array}{c}\% \\
\text { contr } \\
\text { ibuti } \\
\text { on }\end{array}$ \\
\hline A & 1 & $\begin{array}{c}0.332 \\
1\end{array}$ & 0.3321 & $\begin{array}{c}0.16 \\
605\end{array}$ & $\begin{array}{c}0.0010 \\
39\end{array}$ & $\begin{array}{c}16.981 \\
63\end{array}$ & 44.58 \\
\hline B & 1 & $\begin{array}{c}0.021 \\
0\end{array}$ & 0.0210 & $\begin{array}{c}0.01 \\
05\end{array}$ & $\begin{array}{c}0.0010 \\
39\end{array}$ & $\begin{array}{c}16.981 \\
63\end{array}$ & 2.82 \\
\hline $\bar{C}$ & 1 & $\begin{array}{c}0.080 \\
0\end{array}$ & 0.0800 & $\begin{array}{c}0.04 \\
00\end{array}$ & $\begin{array}{c}0.0010 \\
39\end{array}$ & $\begin{array}{c}16.981 \\
63\end{array}$ & 10.74 \\
\hline $\mathrm{AB}$ & 1 & $\begin{array}{c}0.168 \\
2\end{array}$ & 0.1682 & $\begin{array}{c}0.08 \\
41\end{array}$ & $\begin{array}{c}0.0010 \\
39\end{array}$ & $\begin{array}{c}16.981 \\
63\end{array}$ & 22.58 \\
\hline $\mathrm{BC}$ & 1 & $\begin{array}{c}0.045 \\
0\end{array}$ & 0.0450 & $\begin{array}{c}0.02 \\
25\end{array}$ & $\begin{array}{c}0.0010 \\
39\end{array}$ & $\begin{array}{c}16.981 \\
63\end{array}$ & 6.04 \\
\hline $\mathrm{AC}$ & 1 & $\begin{array}{c}0.033 \\
8\end{array}$ & 0.0338 & $\begin{array}{c}0.01 \\
69\end{array}$ & $\begin{array}{c}0.0010 \\
39\end{array}$ & $\begin{array}{c}16.981 \\
63\end{array}$ & 4.53 \\
\hline $\mathrm{ABC}$ & 2 & $\begin{array}{c}0.064 \\
8\end{array}$ & 0.0648 & $\begin{array}{c}0.03 \\
24\end{array}$ & $\begin{array}{c}0.0010 \\
39\end{array}$ & $\begin{array}{c}16.981 \\
63\end{array}$ & 8.70 \\
\hline $\begin{array}{c}\text { Tota } \\
1\end{array}$ & 15 & $\begin{array}{l}0.75 \\
87\end{array}$ & & & & & \\
\hline
\end{tabular}




\section{Conclusion}

From the results obtained it can be predicted that during face milling operation on CF8M material, Depth of cut with its combination with Speed and Feed has more effect for Flatness with $42.53 \%$ and $34.94 \%$ contribution respectively.

Similarly, for Surface Roughness it can be predicted that Speed has more significant effect and contributes to $44.58 \%$ while combination of Speed and Feed has less effect and it contributes to $22.58 \%$.

The future scope of this research work: enhancing the results by performing more number of experiments and changing variables (for example cutter diameter and inserts) and then after plotting obtained results by Minitab or Fuzzy Logic software for comparison purpose.

\section{ACKNOWLEDGEMENT}

The authors thank to Mr. Vivek Thakar of Flovel valves Pvt Ltd., GIDC, VU Nagar, Gujarat, India for their support in providing \& discussing the industrial problem. Even the authors would be grateful to B.C.Instruments India Pvt Ltd, GIDC, VU Nagar for their support that had helps a lot in conducting the experiments.

\section{REFERENCES}

[1] T. Patel, S. Sheth, B.S. Modi, P. Patel, "Experimental investigation and Forecast of Weld penetration in MIG Welding Process on WCB Material", Proceeding of the international conference on Advances in Production and industrial Engineering, 2015, 186-191. DOI: 10.13140/RG.2.1.3550.4163.

[2] S. Sheth, B.S. Modi, T. Patel, P. M. George, "A Fuzzy Logic

Based Model to Predict Weld Width-A Case Study of Hard

Facing Process Using MIG Welding on Dual Plate Check Valve", 594.8

Applied Mechanics and Materials, 592-594 (2014), 8-12. DOI: 10.4028/www.scientific.net/AMM.592-

[3] B. Mistry, P. M George, S. Sheth, "Study and scope of DFMA and GD\&T in manufacturing process: A case study on dual plate check valve", Proceeding of 7th International Conference on Advanced Computing and Communication Technologies (ICACCTTM-2013),2013, DOI: 10.13140/2.1.2294.8642.

[4] Milon D. Selvam,Dr. G. Karuppusami and Dr.A.K.Shaik Dawood, "Optimization of machining parameters for face milling operation in a vertical CNC millingmachine using genetic algorithm", IRACST Engineering Science and Technology: An International Journal (ESTIJ), ISSN: 2250-3498, Vol.2, No. 4, August 2012.

[5] S. Sheth, P. M. George, "Experimental Investigation and Fuzzy

Modelling of Flatness and Surface Roughness for WCB Material

Using Face Milling Operation", In CAD/CAM, Robotics and Factories of the Future, 2016, 769-777, Springer India, DOI: 10.1007/978-81-322-2740-3_74

[6] S. Sheth, P. M. George, "Experimental Investigation and

Prediction of Flatness and Surface Roughness during Face

Milling Operation of WCB Material", Procedia Technology, 23

(2016), 344-351.

[7] Douglas C. Wiley,'Design And Analysis Of Experiments - international student version by Student Edition".

[8] P. J. Patel, S. Sheth, "Effect of Various Parameters on Material

Removal Rate in Flashing Operation of Precision Steel Ball

Manufacturing Process", 1st International and 16th National

Conference on Machines and Mechanisms (iNaCoMM2013), 2013, 332-338. 
[9] P. J. Patel, S. Sheth. P. Chauhan, "Effect of Various Parameters on Spread in Flashing Operation of Precision Steel Ball

Manufacturing Process", Procedia Materials Science, 5 (2014),

2224-2232.

[10] Keyence,"Surface roughness measurement methods from - Introduction to surface roughness measurement". KEYENCE's internal research/evaluation

[11] S. Sheth, B. S. Modi, P. M. George, P. Patel, “A Fuzzy Logic based Model to Predict MRR in Flashing Operation of Precision Steel Ball Manufacturing Process", Procedia Materials Science, 5 (2014), 1837-1845.

[12] S. Sheth, P. M. George, "Experimental Investigation, Prediction and Optimization of Cylindricity and Perpendicularity during Drilling of WCB Material Using Grey Relational Analysis", Precision Engineering, 45 (2016), 33-43. http://dx.doi.org/10.1016/j.precisioneng.2016.01.002

[13] http://www.e6.com/wps/wcm/connect/E6_Content_EN/Home/M aterials+and+products/CBN/

[14] http://ecatalog.mitutoyo.com/Crysta-Plus-M4435747106-Series- 196-Manual-Floating-Type-CMMC1621.aspx

[15] Surasit Rawangwong, Jaknarin Chatthong, Romadorn Burapa, and Worapong Boonchouytan, "An investigation of optimum cutting conditions in face milling semi-solid AA7075 using carbide tool" (2012),International journal of innovation, Vol-3, No. 6, PP 692-696.

[16] https://en.wikipedia.org/wiki/Milling_(machining) 